\title{
Tectorigenin, an Isoflavone of Pueraria thunbergiana BeNTH., Induces Differentiation and Apoptosis in Human Promyelocytic Leukemia HL-60 Cells
}

\author{
Kyung-Tae LeE, ${ }^{a}$ Il-Cheol SoHn, ${ }^{a}$ Young-Kwan KIM, ${ }^{a}$ Jung-Hye CHOI,${ }^{a}$ Jong-Won CHOI, ${ }^{b}$ \\ Hee-Juhn Park, ${ }^{c}$ Yoshie Iтон, ${ }^{d}$ and Ken-ichi Міүамото*,d \\ College of Pharmacy, Kyung Hee University, ${ }^{a}$ Seoul 130-701, Korea, College of Pharmacy, Kyung-Sung University, ${ }^{b}$ \\ Pusan 680-736, Korea, Division of Applied Plant Sciences, Sangji University, ${ }^{c}$ Wonju 220-702, Korea, and Department of \\ Hospital Pharmacy, School of Medicine, Kanazawa University, ${ }^{d}$ 13-1 Takara-machi, Kanazawa 920-8641, Japan. \\ Received February 26, 2001; accepted June 15, 2001
}

\begin{abstract}
Cytotoxic effects of six isoflavonoids, tectorigenin, glycitein, tectoridin, glycitin, $6^{\prime \prime}-O$-xylosyltectoridin, and $6^{\prime \prime}$-O-xylosylglycitin isolated from the flower of Pueraria thunbergiana BENTH. together with genistein, a known differentiation and apoptosis inducer, were examined. Among these isoflavonoids, tectorigenin and genistein exhibited cytotoxicity against various human cancer cells; glycitein showed only mild cytotoxicity. These results suggest that the isoflavone structure and 5-hydroxyl group are crucial for the cytotoxic properties and that glycosides are inactive. Moreover, tectorigenin induced differentiation of human promyelocytic leukemia HL-60 cells to granulocytes and monocytes/macrophages, and caused apoptotic changes of DNA in the cells, as did genistein. Tectorigenin also inhibited autophosphorylation of epidermal growth factor (EGF) receptor by EGF and decreased the expression of Bcl-2 protein, with less activity than genistein. From these results, tectorigenin may be a possible therapeutic agent for leukemia.
\end{abstract}

Key words isoflavone; tectorigenin; cytotoxicity; differentiation; apoptosis; HL-60 cell

In Oriental herbal medicine, the roots of Pueraria thunbergiana are widely used as antipyretics and analgesics in treatment of the common cold, and the flowers of this plant have also been traditionally used to treat diabetes mellitus and lingering intoxification. ${ }^{1}$ From the flowers, the isoflavonoids such as kakkalide together with irisolidone, genistein and daidzein were isolated. ${ }^{2-4)}$ Park et al. recently isolated other isoflavonoids (tectorigenin, glycitin, tectoridin, 6 "'-O-xylosyltectoridin and 6"-O-xyloglycitin) from the flowers of $P$. thunbergiana. ${ }^{5)}$ Further, we have reported the hypoglycemic effect of tectorigenin in streptozotocin-induced diabetic rats ${ }^{6}$ and this effect was presumably caused by the antioxidant effect, partly dependent on free radical scavenging and antilipid peroxidation effect. ${ }^{7}$

Many isoflavones are known to have insecticidal effects as well as beneficial effects on lipid metabolism and cancer. ${ }^{8)}$ It was previously reported that genistein, a protein tyrosine kinase (PTK) inhibitor, induced leukemia cell differentiation and apoptosis, whereas the non-PTK inhibitory isoflavones psi-tectorigenin and daidzein also induce differentiation in human leukemia cell lines. ${ }^{9,10}$ The isoflavone derivatives genistein, daidzein and genistin were reported to have differentiation-induction and antioxidant effects, and these anticancer effects are structurally related to the 4'-hydroxyl group on isoflavones. ${ }^{11)}$ In this study, we examined whether isoflavonoids from P. thunbergiana can induce differentiation and apoptosis in human cancer cells and here we discuss their chemical structure and biological activities.

\section{MATERIALS AND METHODS}

Materials Tectorigenin, tectoridin, glycitein, glycitin, $6 "-O$-xylosyltectoridin and $6 "$-O-xyloglycitin used for this study were isolated from the flower of $P$. thunbergiana BENTH., as previously reported, ${ }^{5)}$ and these structures together with that of genistein are shown in Fig. 1. 3-(4,5-Dimethylthiazol-2-yl)-2,5-diphenyl-tertazolium bromide (MTT), genistein, nitroblue-tetrazolium (NBT), $1 \alpha, 25$-dihydroxyvitamin $\mathrm{D}_{3}\left(1 \alpha, 25(\mathrm{OH})_{2} \mathrm{D}_{3}\right), \quad 12-O$-tetradecanoylphorbol-13-acetate (TPA), $0.2 \%$ latex particle (average diameter, $0.81 \mu \mathrm{m}$ ), cisplatin, RNase A, leupeptin, aprotinin and epidermal growth factor (EGF) were purchased from Sigma Chemical Co. (St. Louis, MO, U.S.A.). Proteinase $\mathrm{K}$ was from Wako Pure Chemical Industries (Osaka, Japan). Fluorescein-isothiocyanate (FITC)-labeled anti-human CD14 and anti-human CD66b mouse monoclonal antibodies were obtained from PharMingen (San Diego, CA, U.S.A.). Anti-Bcl-2 monoclonal antibody and horseradish peroxidase-conjugated goat anti-mouse IgG antibody were from Santa Cruz Biotechnology, Inc. (Santa Cruz, CA, U.S.A.). $\left[\gamma_{-}{ }^{32}\right.$ P]ATP was purchased from Amersham Pharmacia (Buckinghamshire, U.K.).

Cell Culture HL-60 human promyelocytic leukemia, U-
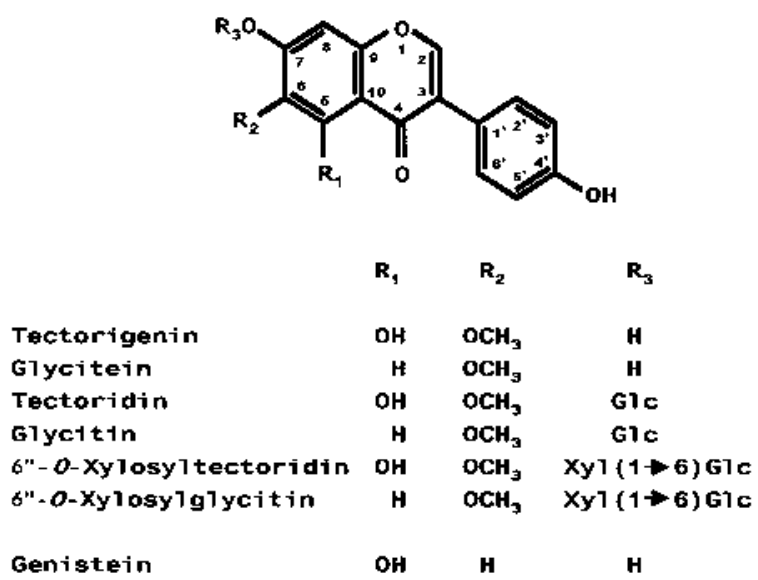

Fig. 1. Chemical Structures of Isoflavonoids Isolated from Pueraria thunbergiana 
937 human histocytic lymphoma, HepG2 human hepatoma, SNU-C4 human colon cancer and A431 human epidermoid carcinoma cell lines were obtained from the Korean Cell Line Bank (Seoul, Korea). These were grown at $37^{\circ} \mathrm{C}$ in RPMI-1640 medium supplemented with $10 \%$ fetal bovine serum, penicillin (100 units/ml), and streptomycin sulfate $(100 \mu \mathrm{g} / \mathrm{ml})$. Cells were grown in a humidified atmosphere of $95 \%$ air $5 \% \mathrm{CO}_{2}$ and were seeded in plates after 3 passages.

Cytotoxicity Assay The in vitro tests against HL-60, U937, HepG2 and SNU-C5 cells were performed using MTT assay, essentially according to the method described previously. $^{12)}$

Determination of Growth Inhibition Cells were seeded at a concentration of $2 \times 10^{5}$ cells $/ \mathrm{ml}$, maintained for logarithmic growth by passaging them every $2-3 \mathrm{~d}$, and incubated for $1-4 \mathrm{~d}$ with tectorigenin and genistein at various concentrations. Tectorigenin dissolved in ethanol was added to medium in serial dilution (the final ethanol concentration in all assays did not exceed $0.05 \%$ ). Cell viability was checked by trypan blue exclusion method.

Differentiation Assay (1) NBT reduction test: The percentage of HL-60 cells capable of reducing NBT was determined by counting the number of cells which contained precipitated formazan particles, after cells had been incubated with NBT $(1.0 \mathrm{mg} / \mathrm{ml})$ at $37^{\circ} \mathrm{C}$ for $30 \mathrm{~min}$. TPA was used as a stimulator for the formation of formazan. (2) Phagocytosis test: HL-60 cells $\left(1 \times 10^{6}\right.$ cells $\left./ \mathrm{ml}\right)$ were suspended in serum free RPMI 1640 medium containing 0.2\% latex particles (average diameter, $0.81 \mu \mathrm{m})$ and incubated at $37^{\circ} \mathrm{C}$ for $4 \mathrm{~h}$. After incubation, the cells were washed once with phosphatebuffered saline (PBS). Cells containing more than 10 latex particles were scored as phagocytic cells. (3) Flow cytometry: HL-60 cells $\left(2 \times 10^{5}\right.$ cells $\left./ \mathrm{ml}\right)$ exposed to tectorigenin were collected and washed twice with ice-cold PBS. They were then incubated with direct FITC-labeled anti-CD14 or anti-CD66b antibody on ice for $60 \mathrm{~min}$, washed twice with PBS, and antibody binding to cells was quantified using FACS flow cytometry (Becton Dickinson Co., Germany).

DNA Fragmentation Assay For assays of fragmentation of chromosomal DNA, $1 \times 10^{6}$ cells were collected by centrifugation and washed two times with PBS. The cells were fixed in $70 \%$ ethanol and stained overnight with propidium iodide $(100 \mu \mathrm{g} / \mathrm{ml})$ in PBS containing RNase A $(500 \mu \mathrm{g} / \mathrm{ml})$ at $4{ }^{\circ} \mathrm{C}$. The hypodiploid DNA was determined by flow cytometry using the Cell Quest program (Becton Dickinson). A portion of cells after incubation was suspended in lysis buffer (10 mm Tris-HCl, pH 8.0, 10 mm EDTA, 0.5\% sodium dodecyl sulfate (SDS) solution). The lysate was centrifuged at $13000 \times \boldsymbol{g}$ for $20 \mathrm{~min}$ to obtain the supernatant containing fragmented DNA. An aliquot $(200 \mu \mathrm{l})$ of the supernatant and the pellet were used for the assay of DNA content. The other half was incubated with $1 \mu \mathrm{g} / \mathrm{ml}$ RNase for $60 \mathrm{~min}$ at $37^{\circ} \mathrm{C}$, followed by treatment with $100 \mu \mathrm{g} / \mathrm{ml}$ proteinase $\mathrm{K}$ for an additional $45 \mathrm{~min}$ at $50^{\circ} \mathrm{C}$. DNAs were preincubated by adding $50 \mu \mathrm{l}$ of $5 \mathrm{M} \mathrm{NaCl}$ and $250 \mu \mathrm{l}$ of isopropyl alcohol at $-20^{\circ} \mathrm{C}$ overnight. DNA samples were resolved by eletrophoresis on 2\% agarose gel. After electrophoresis for $90 \mathrm{~min}$ at $50 \mathrm{~V}$, the gel was stained with ethidium bromide, and DNA was visualized by a UV transilluminator.

Western Blot Analysis Cellular protein was extracted from control and tectorigenin treated-HL-60 cells. The washed cell pellets were resuspended in ELB buffer $(50 \mathrm{~mm}$ HEPES pH 7.0, $250 \mathrm{~mm} \mathrm{NaCl,} 5$ mm EDTA, 0.1\% Nonidet P40, $1 \mathrm{~mm}$ phenylmethylsulfonyl fluoride, $0.5 \mathrm{~mm}$ dithiothreitol, $5 \mathrm{~mm} \mathrm{NaF}, 0.5 \mathrm{~mm}$ sodium orthovanadate) containing $5 \mu \mathrm{g} / \mathrm{ml}$ each of leupeptin and aprotinin and incubated for $15 \mathrm{~min}$ at $4^{\circ} \mathrm{C}$. Cell debris was removed by microcentrifugation, followed by quick freezing of the supernatants. Protein was determined by Bio-Rad protein assay reagent (CA, U.S.A.), as described by the manufacturer. Cellular protein $(200 \mu \mathrm{g})$ from treated and untreated cell extracts was electroblotted onto nitrocellulose membrane following separation on $10 \%$ SDS-polyacrylamide gel electrophoresis (PAGE). The immunoblot was incubated overnight with blocking solution ( $5 \%$ skim milk) at $4{ }^{\circ} \mathrm{C}$, followed by incubation for $4 \mathrm{~h}$ with a 1:500 dilution of anti-Bcl-2 antibody. Blots were washed 2 times with PBS and incubated with a $1: 1000$ dilution of horseradish peroxidase-conjugated secondary antibody for $1 \mathrm{~h}$ at room temperature, washed again three times, and then developed by enhanced chemiluminescence (Amersham Life Science, Arlington Heights, IL, U.S.A.).

EGF-Receptor Kinase Activity A431 cell crude membrane extract was prepared basically as described in Thom et al. ${ }^{13)}$ EGF-receptor autophosphorylation assay was carried out by incubating $2.5 \mu \mathrm{g}$ of A431 membrane fraction in a final volume of $25 \mu \mathrm{l}$ essentially as previously described. ${ }^{14)}$ The membrane EGF receptor was activated with EGF $(1 \mu \mathrm{g} / \mathrm{ml})$ for $10 \mathrm{~min}$ at $0^{\circ} \mathrm{C}$ before being incubated with tectorigenin and genistein at $37^{\circ} \mathrm{C}$, phosphorylation was started by adding $\left[\gamma^{32} \mathrm{P}\right]$ ATP to the mixture for $5 \mathrm{~min}$ at $30^{\circ} \mathrm{C}$, and the reaction was terminated by heating at $95^{\circ} \mathrm{C}$ for $5 \mathrm{~min}$ in SDS-PAGE denaturation buffer. The resulting proteins were subjected to SDS-PAGE, as described. ${ }^{14)}$ The ${ }^{32}$ P-labelled protein band corresponding to the EGF-receptor $(170 \mathrm{kDa})$ was detected by autoradiography.

\section{RESULTS}

Cell Growth Inhibition Cytotoxicities of isoflavonoids from $P$. thunbergiana measured using MTT assay on various human cancer cells are listed in Table 1. Among these compounds, tectorigenin and genistein exhibited cytotoxicity, glycitein showed only mild cytotoxicity and other compounds were inactive. As shown in Fig. 2, tectorigenin and genistein inhibited growth of HL-60 cells in concentrationand time-dependent manners. In the later days of culture with

Table 1. Cytotoxic Activity $\left(\mathrm{IC}_{50}\right)$ of Isoflavones Isolated from $P$. thunbergiana on Cancer Cell Growth in Vitro

\begin{tabular}{lcccc}
\hline \hline & \multicolumn{4}{c}{$\mathrm{IC}_{50}(\mu \mathrm{M})$} \\
& $\mathrm{HL}-60$ & $\mathrm{U}-937$ & $\mathrm{HepG} 2$ & \multirow{2}{*}{ SNUC-5 } \\
\hline Tectorigenin & 22.3 & 28 & 84 & 62.7 \\
Glycitein & 86.4 & 103.5 & 136.5 & 165.8 \\
Tectoridin & $>200$ & $>200$ & $>200$ & $>200$ \\
Glycitin & $>200$ & $>200$ & $>200$ & $>200$ \\
6"- $O$-Xylosyltectoridin & $>200$ & $>200$ & $>200$ & $>200$ \\
6"- $O$-Xylosylglycitin & $>200$ & $>200$ & $>200$ & $>200$ \\
Genistein & 8.5 & 22.2 & 39.9 & 26.7 \\
& & & & \\
\hline
\end{tabular}

Twenty-four hours after seeding, cells were treated with varying concentrations of each compound for $48 \mathrm{~h}$, and the cell viability was measured by the MTT assay as described in Materials and Methods. The values represent the mean of three independent experiments. 
a)

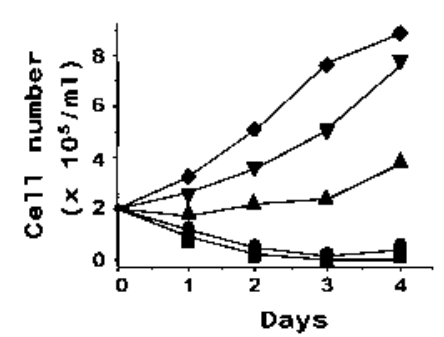

b)

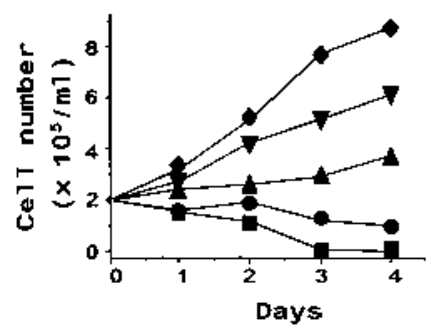

Fig. 2. Effects of Tectorigenin and Genistein on Growth of HL-60 Cells Cells were treated with increasing concentrations of tectorigenin (a: $\bullet$, control; $\nabla$, $10 \mu \mathrm{m} ; \boldsymbol{\Lambda}, 20 \mu \mathrm{M} ; \boldsymbol{\bullet}, 35 \mu \mathrm{M} ; \mathbf{\square}, 60 \mu \mathrm{M}$ ) and genistein (b: $\bullet$, control; $\boldsymbol{\nabla}, 25 \mu \mathrm{M} ; \boldsymbol{\Delta}$, $50 \mu \mathrm{M} ; \bullet, 75 \mu \mathrm{M} ; \mathbf{\square}, 100 \mu \mathrm{m}$ ) for 4 d. Data represent the mean \pm S.D. (within symbols) of three independent experiments.

Table 2. Induction of Differentiation Markers in HL-60 Cells after Treatment with Tectorigenin, Genistein, and $1 \alpha, 25(\mathrm{OH})_{2} \mathrm{D}_{3}$ for $4 \mathrm{~d}$

\begin{tabular}{lccc}
\hline \hline Compound & $\begin{array}{c}\text { Concentration } \\
(\mu \mathrm{M})\end{array}$ & $\begin{array}{c}\text { NBT reduction } \\
(\%)\end{array}$ & $\begin{array}{c}\text { Phagocytosis } \\
(\%)\end{array}$ \\
\hline Vehicle & - & $2.7 \pm 0.4$ & $4.7 \pm 0.5$ \\
Tectorigenin & 50 & $10.7 \pm 2.9^{*}$ & $14.4 \pm 1.6^{*}$ \\
& 75 & $30.9 \pm 2.5^{*}$ & $35.6 \pm 2.0^{*}$ \\
Genistein & 20 & $26.6 \pm 1.9^{*}$ & $16.5 \pm 2.8^{*}$ \\
& 35 & $55.2 \pm 3.9^{*}$ & $64.7 \pm 3.6^{*}$ \\
$1 \alpha, 25(\mathrm{OH})_{2} \mathrm{D}_{3}$ & 0.01 & $61.5 \pm 8.1^{*}$ & $58.1 \pm 3.2^{*}$ \\
\hline
\end{tabular}

Data indicate the percentage of the cells which were stainable with NBT, or took up over 10 latex particles, and are expressed as the mean \pm S.D. of 3 experiments. $* p<0.01$, significantly different from the vehicle control, using Student's $t$-test.

higher doses of these two compounds, the cells were stained with trypan blue, but in limited fractions.

Effect on Differentiation of HL-60 Cells After treatment of HL-60 cells for $4 \mathrm{~d}$, the differentiation inducing activity of tectorigenin was assayed compared with those of genistein and $1 \alpha, 25(\mathrm{OH})_{2} \mathrm{D}_{3}$, and the results are shown in Table 2. When HL-60 cells were incubated with tectorigenin at concentrations of 50 and $75 \mu \mathrm{M}$ for this period, approximately $10.7 \%$ and $30.9 \%$ of HL-60 cells became stainable with NBT, respectively, whereas only $2.7 \%$ of the untreated cells were positive. The other isoflavone analogues, glycitein, tectoridin, glycitin, 6"-O-xylosyltectoridin and 6"-O-xylosylglycitin showed no NBT reducing effect even at the concentration of $200 \mu \mathrm{M}$ (data not shown). Tectorigenin also induced HL-60 cells to differentiate phagocytic cells, but appeared to be weaker than genistein and $1 \alpha, 25(\mathrm{OH})_{2} \mathrm{D}_{3}$. Next, the induction of differentiation was assessed by the expression of cell surface antigens CD14 and CD66b (Fig. 3). Exposure of HL-60cells to 20 and $35 \mu \mathrm{M}$ tectorigenin for $4 \mathrm{~d}$ increased the percentage of cells expressing CD14 antigen from $13.6 \%$ in the blank to $31.9 \%$ and $49.1 \%$, respectively. The peak of expressing CD66b antigen was also shifted to the high fluorescence intensity. These results indicated that tectorigenin induced HL-60 cells to undergo monocyte/macrophage and granulocyte differentiation.

Induction of Apoptosis of HL-60 Cells When tectorigenin and genistein were added to HL-60 cells for $4 \mathrm{~d}$, these isoflavones almost stopped the cell growth at 20 and $50 \mu \mathrm{M}$, respectively (Fig. 2). We therefore compared the effects of these compounds on apoptosis at these concentrations with the effect of positive agent cisplatin $(10 \mu \mathrm{M})$. As shown in (a)

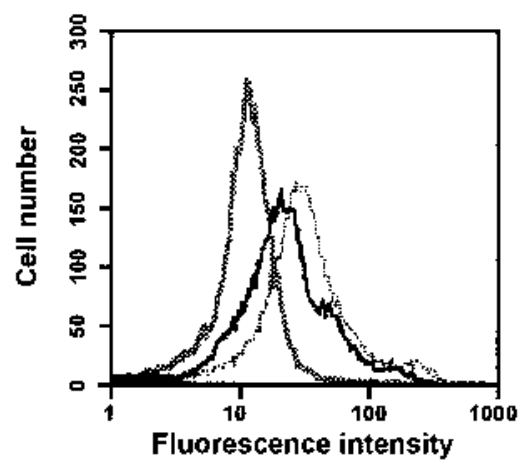

(b)

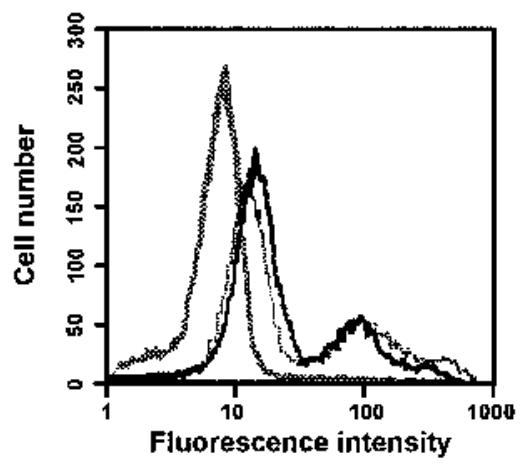

Fig. 3. FACS Analysis of Expression of CD14 (a) and CD66b (b) Antigens in HL-60 Cells by Tectorigenin

HL-60 cells $\left(1 \times 10^{6}\right.$ cells $\left./ \mathrm{ml}\right)$ exposed to various concentration of tectorigenin for $4 \mathrm{~d}$ were collected and washed twice with ice-cold PBS. Cells were then incubated with direct immunofluorescent staining using FITC-labeled anti-CD 14 or anti-CD 66b antibody on ice for $30 \mathrm{~min}$, washed twice with PBS, and antibody binding to cells was quantified using FACS flow cytometry.

Control, $\square ; 20 \mu \mathrm{M},-; 35 \mu \mathrm{M}, \ldots$.

Fig. 4, $50 \mu \mathrm{M}$ tectorigenin and $35 \mu \mathrm{M}$ genistein increased the population of hypodiploids without apparent change in the cell cycle. These compounds also induced nucleosomal ladder-fragmentation (Fig. 5).

Effect on Bcl-2 Expression in HL-60 Cells Figure 6 shows the effects of tectorigenin and genistein on the expression of Bcl-2 protein in HL-60 cells, after treatment for $4 \mathrm{~d}$. Tectorigenin decreased the Bcl-2 protein levels in the cells in a concentration-dependent manner, but its effect was much weaker than that of genistein.

Effect on Autophosphorylation of EGF-Receptor in A431 Cells The PTK activity was determined as a function of phosphorylation of EGF receptor. EGF-receptor autophosphorylation (PTK activity), which occurs under physiological condition, was investigated using a plasma membrane preparation from human epidermoid carcinoma A431 cells. Figure 7 shows an apparent increase in EGF receptor phosphorylation by EGF and dose-dependent inhibition by tectorigenin and genistein. Phosphorylation of EGF-receptor in the absence of EGF (basal phosphorylation) was not detected. The inhibitory effect of tectorigenin was weaker than genistein.

\section{DISCUSSION}

This study indicated that among seven isoflavonoids of $P$. thunbergiana examined, tectorigenin and genistein exhibited 
a stronger growth inhibitory effect on some human cancer cell lines than glycitein. These results suggest that the 5-hydroxyl group on the isoflavone structure is crucial for the cy- (a)

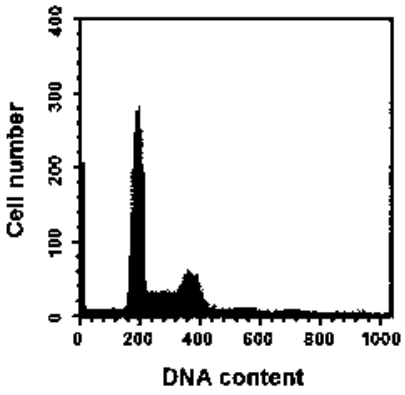

(c)

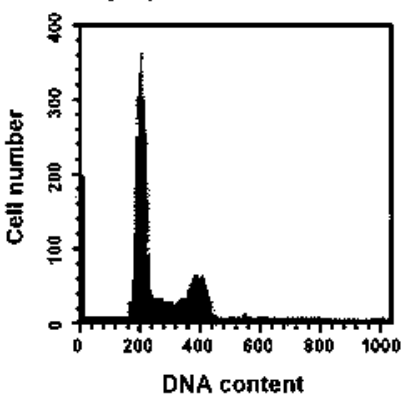

(e)

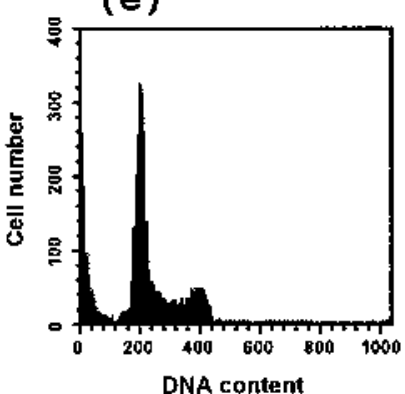

(b)

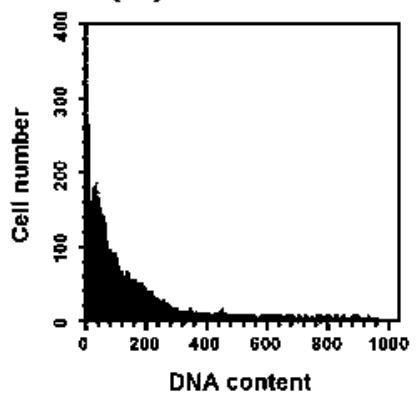

(d)
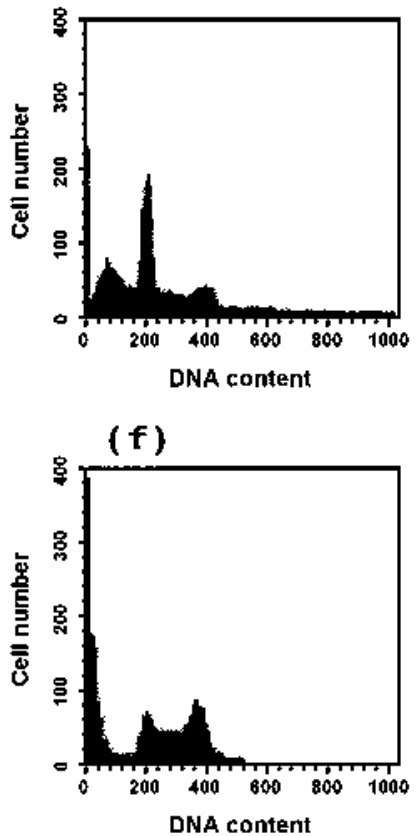

Fig. 4. DNA Fluorescence Flow Cytometry Histograms from HL-60 Cells Treated with Tectorigenin and Genistein for $4 \mathrm{~d}$

DNA from the cells treated with a compound for $4 \mathrm{~d}$ was analyzed by flow cytometry as described in Materials and Methods. (a) control, (b) $10 \mu \mathrm{M}$ cisplatin, (c) $25 \mu \mathrm{M}$ tectorigenin, (d) $50 \mu \mathrm{m}$ tectorigenin, (e) $20 \mu \mathrm{m}$ genistein, (f) $35 \mu \mathrm{m}$ genistein. totoxic properties. Glycosides were inactive however; as previously reported most cytotoxic natural compounds do not belong to glycosides except for the cytotoxic saponin acting on cellular membranes. ${ }^{15,16)}$ In general, hydrophilic compounds with sugar moieties are hardly permeable to the cellular membranes. ${ }^{17)}$ Tectorigenin induced differentiation into granulocytes and/or monocytes/macrophages, as assessed by NBT reduction, latex beads phagocytic activity and CD14 and CD66b antigen expression, and by apoptosis, as assessed by increase in hypodiploid population and DNA ladder formation, of human promyelocytic leukemia HL-60 cells less effectively than genistein. Genistein is well known to have potent PTK inhibitory activity. In this study it was confirmed that genistein strongly inhibited this activity in A431 cells, but to a much less extent than that of genistein. The substitution of the methoxy group at position 6 of the isoflavone skeleton (Fig. 1) may decrease the PTK activity. On the other hand, it has been reported that psi-tectorigenin, which potently inhibits phosphatidylinositol turnover without inhibiting PTK, ${ }^{18)}$ induced differentiation of myelocytic leukemia cells, and the effect was stronger than that of genistein. ${ }^{9)} \mathrm{Be}-$ cause tectorigenin is an isomer of psi-tectorigenin, which has a structure of 8-methoxy isoflavone (Fig. 1), tectorigenin may have inhibitory activity of phosphatidylinositol turnover

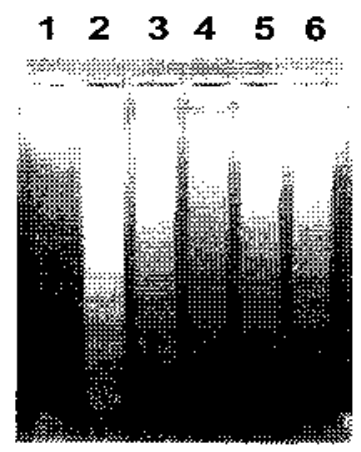

Fig. 5. Analysis of DNA Fragmentation in HL-60 Cells Treated with Tectorigenin and Genistein

Cells were treated without (control) or with tectorigenin or genistein for $4 \mathrm{~d}$, then detergent-soluble cleaved DNA was subjected to electrophoresis on $1.5 \%$ agarose gel electrophoresis, as described in Materials and Methods. Lane 1, control; lane 2, $10 \mu \mathrm{M}$ cisplatin; lane 3, 20 $\mu \mathrm{M}$ genistein; lane 4, 35 $\mu \mathrm{m}$ genistein; lane 5, $50 \mu \mathrm{M}$ tectorigenin; lane $6,100 \mu \mathrm{M}$ tectorigenin.

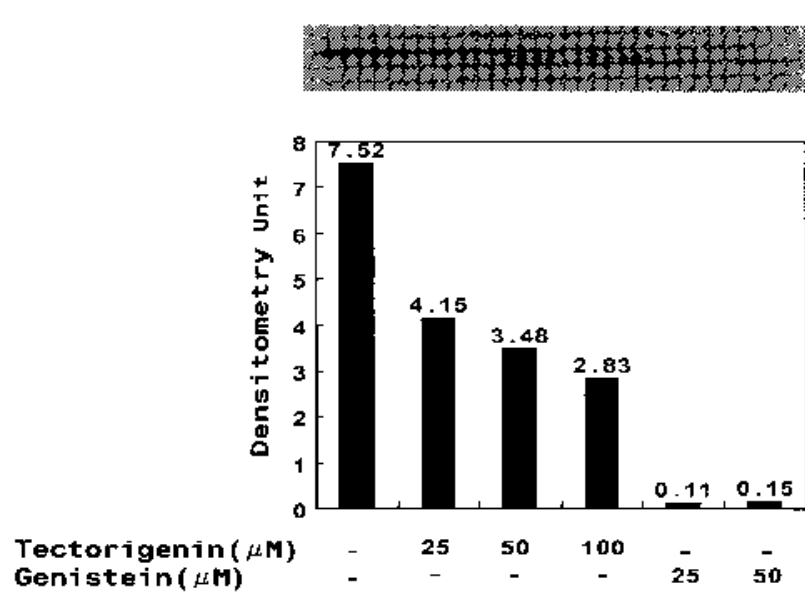

Fig. 6. Western Blot Analysis of Bcl-2 Protein in HL-60 Cells Treated with Tectorigenin and Genistein

Cells were incubated at $37^{\circ} \mathrm{C}$ with tectorigenin and genistein for $4 \mathrm{~d}$. Total protein (100 $\left.\mu \mathrm{g} / \mathrm{lane}\right)$ after lysis was subjected to electrophoresis on $10 \%$ SDS-PAGE gel and blotted with human Bcl-2 monoclonal antibody. 


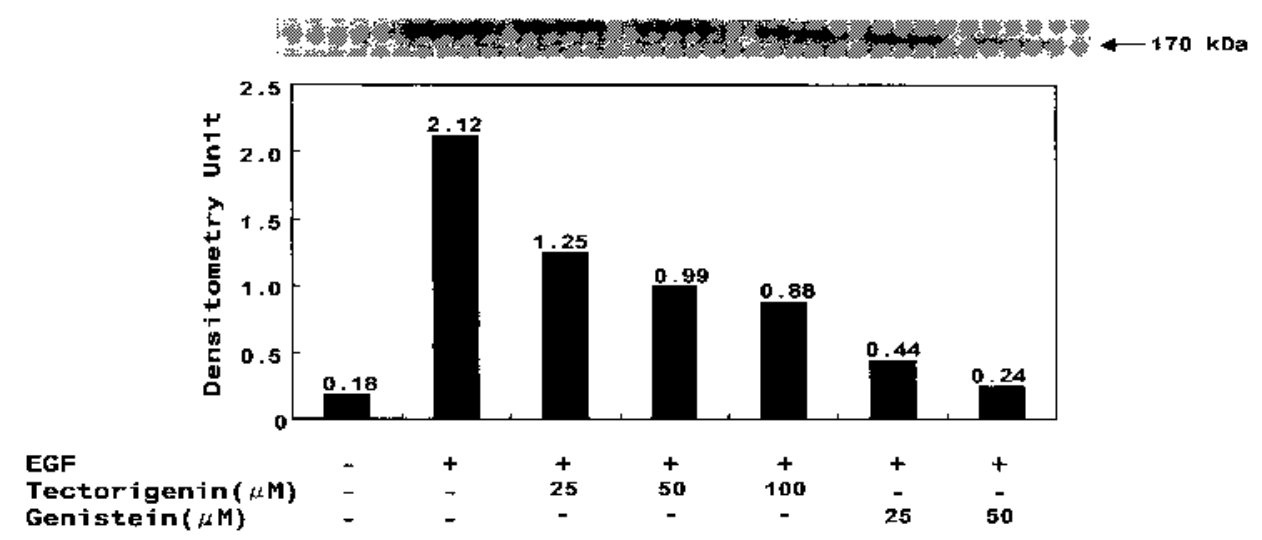

Fig. 7. Effect of Tectorigenin and Genistein on Autophosphorylation of EGF-Receptor in Epidermoid Carcinoma A431 Cells

A431 cell membranes $(2.5 \mu \mathrm{g})$ were incubated for $10 \mathrm{~min}$ with EGF $(1 \mu \mathrm{g} / \mathrm{ml})$ before addition of the indicated concentrations of inhibitors. After 10 min incubation with inhibitors at $37{ }^{\circ} \mathrm{C}$, autophosphorylation reaction was started by addition of radiolabelled ATP and terminated by addition of SDS-sample buffer. An autoradiogram of the dried SDS gel $(8 \%)$ after $2 \mathrm{~h}$ of exposure is shown.

and induce diffrentiation by the same mechanism as psi-tectorigenin.

Protein phosphorylation and dephosphorylation are thought to be key events in the pathways that regulate cell growth, differentiation and apoptosis. ${ }^{19)}$ These are determining factors in the etiology of cancer. In this study, tectorigenin decreased Bcl-2 protein, an apoptosis inhibitory factor, in HL60 cells, as did genistein. ${ }^{20-22}$ Although the inhibition of Bcl-2 expression by these compounds is believed to be closely associated with the induction of apoptosis, the relation between Bcl-2 expression and protein phosphorylation is still unclear.

Although the relationship between leukemic cell differentiation, apoptosis and antiproliferative effects is complex and incompletely understood, differentiation therapy for leukemia, using differentiation-inducing compounds and combinations of various inducers, has been shown to be a new approach in the treatment of some human leukemia; e.g., all transretinoic acid (ATRA) leads to a complete remission of acute promyelocytic leukemia. ${ }^{23)}$ On the other hand, the differentiation inducers ATRA and TPA have been recently shown to induce apoptosis in leukemia cells. ${ }^{24,25)}$ Apoptosis is a form of self-controlled cell death characterized by nucleosomal fragmentation and by several morphological changes which differ from those of necrosis. ${ }^{26)}$ The induction of apoptosis in proliferating tumor cells may thus be useful as an anticancer therapy. Our study showed that tectorigenin exhibited antiproliferative activity against human cancer cells, including HL-60 cells, and this activity may be based upon the induction of differentiation and apoptosis.

Acknowledgement This work was supported by grant No. (2000-2-2090-012-3) from the Basic Research Program of the Korea Science \& Engineering Foundation.

\section{REFERENCES}

1) Kim T. J., "Korean Resource Plants," Vol. 2, Seoul National University Press, Seoul, 1996, p. 232.

2) Kurihara T., Kikuchi M., Yakugaku Zasshi, 95, 1283-1285 (1975).
3) Kurihara T., Kikuchi M., Yakugaku Zasshi, 93, 1201-1205 (1973).

4) Kubo M., Sasaki M., Namba K., Naruto S., Nishimura H., Chem. Pharm. Bull., 23, 2449-2451 (1975).

5) Park H. J., Park J. H., Moon J. O., Lee K. T., Jung W. T., Oh S. R., Lee H. K., Phytochemistry, 51, 147-151 (1999).

6) Lee K. T., Sohn I. C., Kim D. H., Choi J. W., Kwon S. H., Park H. J., Arch. Pharm. Res., 23, 461-466 (2000).

7) Lee K. T., Choi J. W., Park H. J., Kim D. H., Yahak Hoeji, 43, 736742 (1999).

8) Barnes S., Peterson T. G., Proc. Soc. Exp. Biol. Med., 208, 103-108 (1995).

9) Makishima M., Honma Y., Hozumi M., Sanpi K., Hattori M., Umezawa K., Motoyoshi K., Leukemia Res., 15, 701-708 (1991).

10) Jing Y., Nakaya K., Han R., Anticancer Res., 13, 1049 -1054 (1993).

11) Jing Y., Waxman S., Anticancer Res., 15, 1147-1152 (1995).

12) Park H. J., Lee M. S., Lee K. T., Sohn I. C., Han Y. N., Miyamoto K., Chem. Pharm. Bull., 47, 1029-1031 (1999).

13) Thom D., Powel A. J., Lioyd C. W., Rees D. A., Biochem. J., 168, 187-194 (1977).

14) Agostinis P., Vandenbogaerde A., Conella-Deana A., Pinna L. A., Lee K. T., Goris J., Merlevede W., Vandenheede J. R., De Witte P., Biochem. Pharmacol., 49, 1615-1622 (1995).

15) Delmas F., Giorgio C. D., Elias R., Gasquet M., Azas N., Mshvildadze V., Dekanosidze G., Kemertelidze E., Timon-David P., Planta Medica, 66, 343-347 (2000).

16) Izumi T., Piskula M. K., Osawa S., Obata A., Tobe K., Saito M., Kataoka S., Kubota Y., Kikuchi M., J. Nutr., 130, 1695-1699 (2000).

17) Li L., Wang H. K., Chang J. J., McPhail A. T., McPhail D. R., Terada H., Konoshima T., Kokumai M., Kozuka M., Estes J. R., J. Nat. Prod., 56, 690-698 (1993).

18) Imoto M., Yamashita T., Sawa T., Kurasawa S., Naganawa H., Takeuchi T., Baoquan Z., Umezawa K., FEBS Lett., 28, 43-46 (1988).

19) Hunter T., Cell, 50, 823-829 (1987).

20) Ponnathpur V., Ibrado A. M., Reed J. C., Ray S., Huang Y., Self S., Bullock G., Nawabi A., Bhalla K., Clin. Cancer Res., 1, 1399-1406 (1995).

21) Constantinou A. I., Kamath N., Murley J. S., Eur. J. Cancer, 34, 1927-1934 (1998).

22) Li Y., Bhuiyan M., Sarkar F. H., Int. J. Oncol., 15, 525-533 (1999).

23) Chomienne C., Fenaux P., Degos L., FASEB J., 10, 1025-1030 (1996).

24) Martin S. J., Bradley J. G., Cotter T. G., Clin. Exp. Immunol., 79, 448-453 (1990).

25) Terui Y., Furukawa Y., Sakoe K., Ohta M., Saito M., J. Biochem. (Tokyo), 117, 77-84 (1995).

26) Gunji H., Hass R., Kufe D., J. Clin. Invest., 89, 854-860 (1992). 